\title{
A Study on Self-Efficacy and Love Styles in Couples with and Without Family Conflicts
}

\author{
Maryam 0jaghi* and Mohammad Narimani \\ Department of Psychology, Ardabil Branch, Islamic Azad University, Ardabil, Iran \\ *Corresponding author: Maryam Ojaghi, Department of Psychology, Ardabil Branch, Ardabil, Islamic Azad University, Iran
}

\begin{abstract}
This study was carried out in order to compare the self-efficacy and love styles in families during divorce and normal families. The study method was scientific-comparative. The study population included individuals with normal lives and individuals going through divorce. The study sample included 50 individuals who were going through divorce process and 50 individuals from normal families. In order to study and collect data. The following questionnaires were used:

a. Self-Efficacy scale developed by Sherer and Adams

b. Love Styles scale developed by Sternberg.

The collected data was analyzed by MANOVA. The findings suggested that there was a significant difference in self-efficacy and love in individuals going through divorce and normal individuals in all aspects at 0.05 . Hence, the results from the study show that individual going through divorce have lower self-efficacy and love and have higher marital conflicts.
\end{abstract}

Keywords: Self-Efficacy; Love; Family Conflicts

\section{Introduction}

Family is a type of social system and an emotional unit that that develops the personality of the individuals. In order for the family to be able to carry out its key functions well, it is necessary for it to have security and peace. In fact, during the processes of family, there are problems that disturbs its peace, even for a short time. (Ritzer, 2004) When family functions, such as its biological, social, cognitive and emotional functions are damaged one after another, the family members lose their sense of satisfaction gradually. The gradual decrease in the sense of satisfaction in the family members, leads to mental break and subsequently social break and ultimately a legal event that is referred to as "divorce" [1]. A quick look at the brief history of family system suggests that there have been conflict and divorce, as long as marriage has existed, and this has been always present during human civilization [2]. According to the official statistics, 200 marriages lead to divorce, among everyone thousand marriages and Iran is the fourth country in the world in this regard [3]. The quality of marital relationships is a multidimensional concept ad it includes various aspects of the couple relationships, such as adaptability, satisfaction, happiness, solidarity and commitment. (Gottman, 1993). Among the most significant components affecting success and adaptability and fit in positive psychology field is self-efficacy that is derived from [4] social psychology theory.

In this approach, human behavior is not only controlled by the external and environmental factors, but also the "cognitive processes have a determining role in this behavior [5]. Bendura believes that self-efficacy refers to the individuals' beliefs and judgements about their capabilities in carrying out a task or coping with a special stressful situation and he sees the characteristics of the individuals with high self-efficacy comparing to the individuals with low self-efficacy in controlling the hardships of life and carrying out their duties and showing more perseverance and better function. (Bendura, 1995) There are some researches carried out to study the relationship between self-efficacy and mental health or adaptation [6]. carried out a research entitled "Sexual Efficacy and Marital Satisfaction". The findings from this study show that there is a significant correlation between sexual efficacy in couples and marital satisfaction. In a study entitled "Modeling Loneliness Based on the Structure of Spiritual Wellbeing of Self-Efficacy and Life Satisfaction", [7] showed that general self-efficacy has a negative 
and significant influence on loneliness in the individuals. On a study carried out on males suffering from sexual disorders, McCullough and [8] came to this conclusion that there is relationship between sexual self-efficacy and life satisfaction. There are many factors involved in any marriage that lead to marital satisfaction and dissatisfaction. According to Rizavy (1996), the main reason for marriage and divorce are love and lack of love. According to him, perceiving the phenomenon of love is important and research in this field seem necessary, for it could lead to clarifying many issues regarding family matters [9].

Love has a significant tole in marital satisfaction and love and truest among the couples is the first motivation in adaptation and conflict resolution [10]. are many different approaches towards the psychologic nature of love and its components, and among the current theories about the loving relationships among the couples, [11] Triangular Love theory is of the most prominent theories. Studies introduce the presence of love in the marital relationships as a strong predicting factor for happiness, positive emotions and satisfaction. (Kim and Hetfield, 2005). In Riehl-Emre, Thomas and Willy (2003) study that was carried out on normal couples and couples dealing with long-term martial issues, live had the highest rate, among other 19 variables. Other studies also showed deep and significant relationships between romantic love and general happiness, lower illness symptoms, higher marital satisfaction and better physical health [12-14]. carried out a research to study the martial issues and the results suggested that the most common problems include sexual issues (23.8\%), emotional intimacy $(18.7 \%)$, cleaning the house $(18 \%)$ and communication $(15.3 \%)$ In the meanwhile, the values of commutation, commitment, decision-making, emotional intimacy and sexual issues have the most negative influence on the marital satisfaction. As it was stated before and as it was shown by the researches, there are many factors affecting stability and continuity of marriage and as a result the prevention of divorce. Hence, considering the abovementioned issues, the objective in this study is to answer this question that if there is a relationship between self-efficacy and love styles in emergence or absence of family conflicts.

\section{Statistical Population}

The statistical population in this study included couples admitted in Dispute Resolution Council of Ministry of Justice in Ardabil County during spring and summer of 2004.

\section{Research Sample}

The sample in this research included 100 individuals who had filed for a divorce and normal families who were chosen through simple random sampling. ( $\mathrm{N}=100)$ The participants selection method was as the following: 50 individuals $(25$ male and 25 female) were randomly chosen among the individuals who had filed for a divorce at the Dispute Resolution Council of Ministry of Justice in Ardabil County. In this study, 50 individuals were considered for each group (divorce applicants and normal individuals).

\section{Data Collection Instruments}

\section{The instruments used in this study included two scales of}

a. Self-Efficacy scale developed by Sherer and Adams

b. Love Styles scale developed by Sternberg

\section{Self-Efficacy scale developed by Sherer and Adams}

This scale was constructed by Sherer and Damas (1983) and it is a paper-pencil questionnaire. The Cronbach's alpha and retest reliability for this scale were reported to be 79 percent and 39 percent, respectively. Mehrabizade Honarmand and Abolqasemi (2000) reported the Cronbach's alpha and retest reliability of the scale to be 81 percent and 79 percent, respectively. It evaluates the self-efficacy of the individuals in three levels of: 1 . The desire for behavior initiation 2 . The desire to try for completing the behavior 3. Their resistance towards the obstacles (Sherer and Adams, 1982) This scale includes 17 items and the participants respond to each item in a 5-point scale (from Completely Disagree to Completely Agree). The validity of this scale was reported to be 91 percent by [1].

\section{Love Styles scale by Sternberg}

Love Styles questionnaire was developed by This scale includes 45 items and assesses three components: intimacy, passion and commitment. [11] reported the Cronbach's alpha of this scale to be 90 percent that is in accordance with the study of Amanollahifard (2006) and he reported 89 percent of the component of intimacy, 89 percent for passion and 81 percent for commitment. [11] calculated the coefficient of validity for components of intimacy, passion and commitment to be 66 percent, 77 percent and 92 percent, respectively [8] .

\section{Statistical Methods}

In order to analyze the data, SPSS software was used and since there are more than one dependent variable in this study and the independent variable is constituted of two independent levels, MANOVA was sued. MANOVA was used in data analysis of $\mathrm{H} 2$. MANOVA was used in order to determine the significance among the groups (filed for divorce and normal) in each of the components of self-efficacy and love styles, and since for MANOVA test the presupposition of equality of variances should be met Table 1, initially Levine test was used and its results are presented in the following table. As it could be observed in Table 2, the presupposition of equality of variances for MANOVA is met, so that this test was not significant for any of the variables, and as a result, parametric MANOVA could be used. However, initially Wilks' lambda test was used to determine the general influence of group variable on the research variables, and its results are presented in (Tables 3 \& 4). Considering the results provided in the table above, in which the general influence of the groups is significant, since the F related to Wilks' lambda with 48.291 is significant with degree of freedom at 
$\mathrm{p}<0.001$; that is, there is a significant difference between the two groups (filed for divorce and normal) at least in one of the research variables. According to the table, it could be inferred that: There is a significant difference between the studied groups (filed for divorce and normal) in the variable of self-efficacy at $p<0.001$. hence, by referring to the mean of the two groups it could be concluded that normal families have a considerably higher self-efficacy, comparing to the families that have filed for divorce. The difference between the studied groups (filed for divorce and normal) is significant in sub-component of intimacy for the love style at $\mathrm{p}<0.001$. hence, by referring to the mean of the two groups it could be concluded that normal families use more love styles, comparing to the families that have filed for divorce.

Table 1: Results of Mean and Standard Deviation of Self-Efficacy and Love Components (Intimacy, Passion and Commitment) Based on Research Groups (Filed for Divorce and Normal).

\begin{tabular}{|c|c|c|c|c|}
\hline Variable & Groups & Mean & Standard Deviation & Number \\
\hline \multirow{3}{*}{ Self-Efficacity } & Filed for Divorce & 57.84 & 10.44 & 50 \\
\hline & Normal & 70.58 & 7.32 & 50 \\
\hline & Total & 64.21 & 11.02 & 100 \\
\hline \multirow{3}{*}{ Intimacy } & Filed for Divorce & 62.66 & 25.24 & 50 \\
\hline & Normal & 122.22 & 17.99 & 50 \\
\hline & Total & 92.44 & 37.03 & 100 \\
\hline \multirow{3}{*}{ Passion } & Filed for Divorce & 56.62 & 26.63 & 50 \\
\hline & Normal & 110.72 & 14.38 & 50 \\
\hline & Total & 83.67 & 34.53 & 100 \\
\hline \multirow{3}{*}{ Commitment } & Filed for Divorce & 64.56 & 31.34 & 50 \\
\hline & Normal & 128.82 & 15.47 & 50 \\
\hline & Total & 96.69 & 40.59 & 100 \\
\hline
\end{tabular}

Table 2: Levine Test for Testing Equality of Variances.

\begin{tabular}{|c|c|c|c|c|}
\hline Variables & $\mathbf{F}$ & $\mathbf{D f}_{\mathbf{1}}$ & $\mathbf{D f}_{\mathbf{2}}$ & Significance Level \\
\hline Self-Efficacy & 1.502 & 1 & 98 & 0.214 \\
\hline Intimacy & 0.041 & 1 & 98 & 0.960 \\
\hline Passion & 0.046 & 1 & 98 & 0.955 \\
\hline Commitment & 1.304 & 1 & 98 & 0.277 \\
\hline
\end{tabular}

Table 3: Manova Significance Test.

\begin{tabular}{|c|c|c|c|c|c|c|}
\hline Test & Value & F & $\begin{array}{c}\text { Degree of } \\
\text { Freedom }\end{array}$ & $\begin{array}{c}\text { Error Degree of } \\
\text { Freedom for }\end{array}$ & Significance Level & Eta-Square \\
\hline Wilks' Lambda & 0.281 & 48.091 & 5.000 & 94.000 & 0.001 & 0.719 \\
\hline
\end{tabular}

Table 4: Manova test for Determining the Difference between Groups in the Studied Variables.

\begin{tabular}{|c|c|c|c|c|c|c|c|}
\hline Change Source & Variables & Sum of Squares & $\begin{array}{c}\text { Degree of } \\
\text { Freedom }\end{array}$ & $\begin{array}{c}\text { Mean of } \\
\text { Squares }\end{array}$ & F & $\begin{array}{c}\text { Significance } \\
\text { Level }\end{array}$ & Eta-Square \\
\hline Groups & Self-Efficacy & 4057.690 & 1 & 4057.690 & 49.838 & 0.001 & 0.337 \\
\hline & Intimacy & 88684.840 & 1 & 88684.840 & 184.557 & 0.001 & 0.653 \\
\hline & Passion & 73170.250 & 1 & 73170.250 & 159.732 & 0.001 & 0.620 \\
\hline & Commitment & 103233.690 & 1 & 103233.690 & 168.971 & 0.001 & 0.633 \\
\hline
\end{tabular}

\section{Discussion and Conclusion}

The first hypothesis in this study was that there is a significant difference between the two groups of families with family disputes and normal families. Based on the derived results, the mean differences between these two groups were significant. Hence, this hypothesis is approved. Therefore, it could be claimed that the couple self-efficacy is higher in the normal individuals, comparing to the individuals going through family disputes. In fact, the findings show that individuals who consider themselves more efficient, have a higher life satisfaction and in addition to having more control in life difficulties, they show a higher effort and persistence in performing their marital tasks and duties, have better performance and can fulfill a desirable future. Hence, the results from this study are in accordance with the findings of Kim and Park, DiThomas et al., Whitie and McLogin, that suggest individuals with higher selfefficacy, in addition to achieving more successes in their lives in performance, have a higher life satisfaction in their marital life. The second hypothesis in this study was that there is a difference between love styles among the couples in two groups of families with family disputes and normal families. According to the results, 
the difference between love styles means in normal individuals and individuals who have filed for divorce was statistically significant, and since the main reason for both marriage and divorce is presence or lack of love, love and trust between the couples is the main motivation for adaptation and conflict resolution, this hypothesis is approved. Accordingly, this study is in accordance with the previous studies of [4] and Pella, that indicate that commitment, intimacy and amount and type of sexual relationships are among the main factors related to love and marital satisfaction. Also, $[7,8]$ showed that there is a positive and significant relationship between love and its styles and martial satisfaction, and the mean of marital satisfaction is higher in the normal families with complete love style, comparing to the individuals going through divorce.

The next research hypothesis that is on the sub-components of love styles, expresses that there is a difference between the intimacy of the styles among the couples in two groups of families with family disputes and normal families. Hence, considering the findings, this hypothesis is approved and statistically significant. Another research hypothesis that is on the sub-components of love styles, expresses that there is a difference between the passion of the styles among the couples in two groups of families with family disputes and normal families. Hence, considering the findings, this hypothesis is approved and statistically significant. Another research hypothesis that is on the sub-components of love styles, expresses that there is a difference between the commitment of the styles among the couples in two groups of families with family disputes and normal families. Hence, considering the findings, this hypothesis is approved and statistically significant.

\section{References}

1. Fatehi Dehaghani A, Nazari M (2010). Sociological Analysis of Factors Affecting Couples Orientation to Divorce in Isfahan Province. Journal of Social Security Studies, p: 31-49.

2. Moshki M, Nouqabi D, Moslem A (2010) Study of the characteristics and factors related to divorce from the viewpoint of divorced couples in Gonabad city in the years 87-88. Center for Social Development and Health Promotion affiliated to Gonabad University of Medical Sciences.
3. Yousefi N, Sohrabi A (2 011) Comparison of the Effectiveness of Family Therapy Approaches Based on the Presence of Mind and Meta-Cognition on the Quality of Marital Relationships among Patients on the Eve of Divorce. Quarterly Journal of Counseling and Psychotherapy.

4. Bandura A (1997) Self-efficacy: The exercise of control. New York: Freeman.

5. Arabian A, Khodapanahi MK, Heydari M, Sedghpour S (2004) The Study of the Relationship between Self-Efficacy Beliefs on Mental Health and Academic Achievement of Students. Journal of Psychology 8(32): 360371.

6. Vaziri Sh, Lotfi Kashani F, Hosseinian S, Bahram Ghaffari S (2010) Sexual self-efficacy and marital satisfaction. Quarterly of Thought and Behavior 4(16): P1-19.

7. Hooman HA, Ahadi H, Sepah Mansour M, Sheikhi M (2010) Modeling of loneliness based on the structure of spiritual well-being of selfefficacy and life satisfaction. Scientific-research journal of psychological research 7: 19-33.

8. McCullough AR, Bull S (2004) Relationship of self- diagnosed prcmature ejaculation to other indicators of male sexual function. Journal Urol-AuA Annu Meeting 171: 233-234.

9. Mahmoudi Gh, Hafez alkotob L (2010) Relationship between love making style and marital satisfaction, psychology research. Islamic Azad University 2(6): 101-114.

10. Qamarani A, Jafar Tabataba'i S (2006) Investigating the Relationship Between Iranian Couples Love and Its Relationship with Satisfaction. New Developments and Consulting Researches 5(17): 95-111.

11. Strenberg R (1998) Love is a sort_A new theory of relationships, oxford university press.

12. Henry RG, Miller RB (2004) Marital problems accuring in midlife: Implications for couples therapists. The American Journal of family therapy 32(5): 405-417.

13. Kim YM(2002) correlation of mental health problems with psychological constracts in adolescens. International Journal of Nursing studies, pp: 139-193.

14. Mashak R (2010) Relationship of love styles (intimacy, pleasure and commitment) with marital satisfaction of married students. Women's and Culture Quarterly, pp: 83-97.

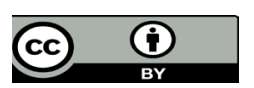

This work is licensed under Creative Commons Attribution 4.0 License

To Submit Your Article Click Here: Submit Article

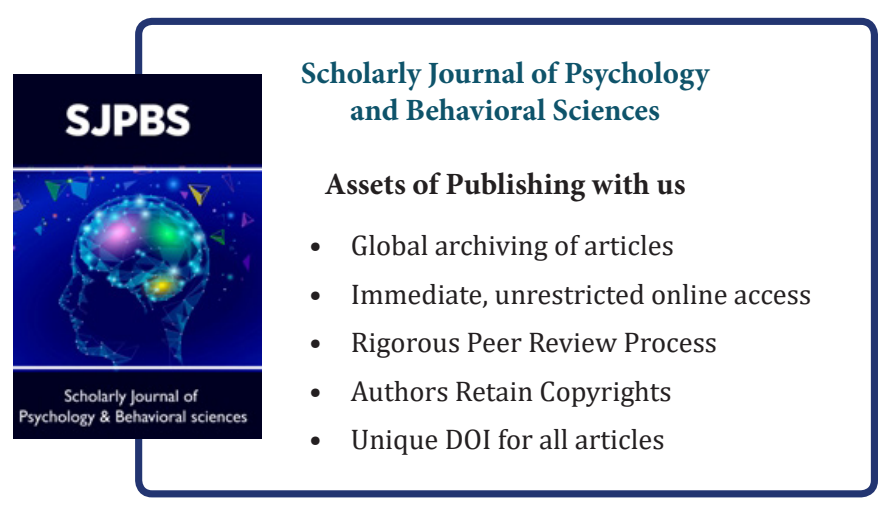

